cesophagus one day during the month of October, 1873. From this time he experienced great difficulty in swallowing, and in May, 1874, died from widespread epithelial ulceration of the middle portion of the osophagus.

In neither of these cases was the obstruction so complete after the sudden onset as in Mr. Thornton's case. Possibly the nervousness of Major — rendered his symptoms more severe. I would suggest, as the most probable solution of the first case, that of temporary obstruction of the osophagus in a lady, that the piece of meat which lodged in the œsophagus was still there when the bougies were passed, and was the immediate cause of the obstruction of the right side of the tube. I remain, Sir, yours obediently,

Queen Anne-street, W., April 16th, 1881. HenRy 'T. ButLin.

\section{THE CHLOROTIC MURMUR.}

\section{To the Editor of THE LANCET.}

SIR,-I did endeavour "to use the utmost care not to misinterpret" Dr. Balfour's views. My statement, for it was not a criticism, to which he has taken exception, referred solely to the basic cardiac murmurs of chlorosis, as the context distinctly shows. I had taken it for granted that a murmur heard over the præcordia was cndocardial, and in discussing the points for and against its being organic or functional, I say "the so-called functional murmurs are always systolic, and are either aortic pulmonary or mitral ;" adding in a foot-note, "Naunyn, George Balfour, and others deny that the inorganic murmurs of chlorosis are ever arterial, and say that they are due to mitral regurgitation," meaning by the term arterial aortic and pulmonary basic murnurs. After again carefully reading Dr. Balfour's Chapter vi., and referring to the paragraphs quoted in my letter of Feb. $19 \mathrm{th}$, I still thisk that my conclusion was logically correct. I also fail to see that Dr. Balfour anywhere indicates that "the ultimate resutt logically and pathologically must be a systolic aortic murmur."

I differ from Dr. Balfour in thinking the opinions of Hayden and Fothergill beside the mark; on the contrary, they seem to me forcible arguments against his explanation of the reduplicated second sound. I am aware that Ceradin states that the "systolic closure of the valves," as he terms it, is attended by the production of sound ; but I understand that this point is difficult to prove and is not ascepted as established by physiologists. If this systolic closure is noiseless, Dr. Balfour's explanation cannot hold. But granting, for the moment, that the "systolic closure" is attended by sound, I am still disposed to doubt the corrctness of Dr, Balfour's view-viz., that the separation between the systolic and diastolic closure of the segments of the pulmonary valve, caused by the increase of the arterial blood pressure within the pulmonary circuit, is the only rational explanation of a reduplicated sound.

In the normal condition of the blood tension the diastolic closure of the valve, which results from the elastic recoil of the vessel, follows so immediately after the systolic closure that the resulting sound (the normal second sound) is single. Is there any reason for supposing that where the blcod tension is increased the "diastolic closure"-i.e., the recoil of the vessel-will be postponed? Should we not rather expect that, if anything, it would be anticipated?

With all respect, then, to Dr. Balfour's great authority, I am disposed to think that the view which I adopted in my lecture is a more probable explanation than the one which he has advaneed. - I am, Sir, your obedient servant,

Edinburgh, April 16th, 1831.

BYroM BRAMWELL.

* This discussion must now close.-ED. L.

\section{PROVIDENT DISPENSARIES IN MANCHESTER AND SALFORD.}

To the Editor of THE LANCET.

SIR,-In THE LANCET of March 26th you refer to Provident Dispensaries as institutions, of a public character with which several medical men are connected, and to which the working classes subscribe. It is time that publicity was given to what they really are, and to the manner in which they are conducted here.

About five years ago, in conjunction with five others, I was surgeon to a provident dispensary. It was quite exception when the rules with regard to the axmission of members were carried out, and when the nembers oi the medical staff complained they were told that if these rnles were enforced it would make the dispensary unpopular. TiE LANCET is mistaken in imagining that these places are worked by any surgeons in the district who like to jill. That was the case formerly, but not now. it doctor $\mathrm{i}$ : engaged by the committee. He takes a private house in a district remote from the dispensary, so that his future private practice may not be injured. Handbills publishing his nom and private address are circulated in the neighbourinood, and by means of a collector the private patients of the other doctors are canvassed and pressed to become members. $t: a$ matter of fact I can point to numerous instances of shop keepers who are being attended at a provident dispensiry. But what can be expected of an Associdtion the Presldent ot which dared to state at a public meeting held in support of these places that doctors in Manchester rept black lists, and were frequently the means of bringing persons to tile workhouse? Theoretically a philanthropical and generous scheme, at its commencement equally generously suppotei by the general practitioners; practically a scheme whinh has deliberately broken faith on every point with the nedical men, and which is worked entirely on the pincisle of silcest no matter at what cost of honourable aud siraightion professional dealing.- $1 \mathrm{am}$, Sir, yours faith fully,

Broughton, Salford, April 13th, 1881.

G. HOLTDY PLAER,

\section{THE SIGNIFICANCE OF DESQUAMATIOA. To the Editor of THE LANCET.}

$\mathrm{SIR}_{3}-\mathrm{I}$ have noticed lately a very important discussion in your columns on the subject of desquamation after scarlet fever. My view of that subjest is that the variation in the process itself is some excuse for the variety of opinion sis to its duration which obtains in the profession. Hay I draw your attention to another cause of desquamation, as it seems to me-the administration or use of certain drugs, suel as turpentine, perhaps copaiba, \&c.? It wonld be extremels interesting to learn the experience of your numerons readers in regard to this point. I lately attended a gentleman in a large hotel for somewhat persistent hematuria, to which he had been liable for about twenty years. Gallie acid having failed, I gave oil of turpentine. Marlied desmaunation in large flakes of the skin of the hands followed, wisch surryested a scarlatinous element so strongly that he was detiined on account of it, and disinfecting precautions were talist. The question was very important, involving questions of deten. tion, and expense, and sanitary law. There was absolutely no other sign of scarlatina, which was indeed almost exc'nded by the history of the case, a very slow pulse, normal temperature, \&e. I have seen two or three chlher cases mure or less similar, with the particulars of which I need not trouble you, but we have a good deal to learn ret about desquamation. Your obedient servant, March, 1881.

MIGILAX:

\section{"MISSED LABOUR."}

To the Editor of THE LANCFT.

SIR, - Reading the discussion on so-called "missel labour" at the meeting of the Obstetrical Societr, I was reminded of a case $I$ had a few years ago. A womm, ajod about forty-five years, who had had six or seven clitilued, consulted me as to her health. She said she was six montl. pregnant, had quickened six weeks ago, and had felt the movements of the child up to a few days aro, when they ceased, and she began to feel "out of sorts," compluined of coldness and weight at the bottom of the body, 30.5 of appetite, and general malaise. The abdomen appeared as large as that of a woman six or seven months aframeel in pregnancy. She looked sallow, almost jaunfliced. A Fiort course of medicine soon removed these ailuents, zal she seemed quite well. I did not see her again until alout twe months after, when she said she was rery well, and luoked so. The abdomen was so much less that any enlurement could scarcely be seen, and she expressed a douvt as tc having been pregnant at all, but thought it was "the changt of life." She still felt a little weight at the bottom of he 